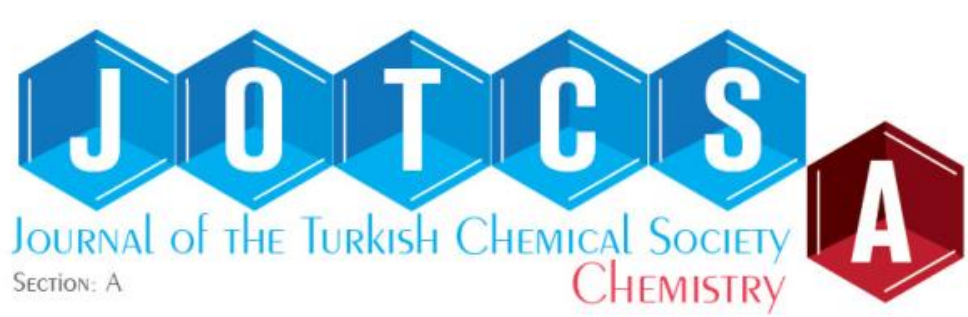

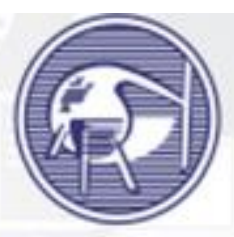

TURKISH

CHEMICAL SOCIETY

\title{
The catalytic activity of Palladium(II) complexes containing PN ligands in the Heck and Suzuki $C-C$ coupling reactions
}

\author{
Mustafa Kemal Yılmaz ${ }^{a,}{ }^{*}$ Mustafa Keleş ${ }^{b}$ \\ aMersin University, Faculty of Arts and Sciences, Department of Chemistry, 33343 Mersin, \\ Turkey \\ ${ }^{b}$ Osmaniye Korkut Ata University, Faculty of Arts and Sciences, Department of Chemistry, \\ 80000 Osmaniye, Turkey
}

\begin{abstract}
A range of iminophosphine (PN) ligands $\left(\left(\mathrm{C}_{6} \mathrm{H}_{5}\right)_{2} \mathrm{P}-\mathrm{C}_{6} \mathrm{H}_{4}-\mathrm{CH}=\mathrm{NR}\left(\mathrm{R}=-\mathrm{C}_{6} \mathrm{H}_{3}\left(2-\mathrm{CH}_{3}\right)(4-\right.\right.$ $\mathrm{OH})(\mathbf{1 a}),-\mathrm{CH}_{2} \mathrm{CH}_{2} \mathrm{C}_{6} \mathrm{H}_{4}(4-\mathrm{OH})(\mathbf{1 b})$ and $\left.-\mathrm{C}_{5} \mathrm{H}_{3} \mathrm{~N}\left(2-\mathrm{CH}_{3}\right)(\mathbf{1 c})\right)$ have been synthesized starting from 4-amino-3-methylphenol, 4-(2-aminoethyl)phenol and 2-amino-3-methylpyridine with 2(diphenylphosphino)benzaldehyde. The $\mathrm{PN}$ ligands were reacted with $\mathrm{Pd}(\operatorname{cod}) \mathrm{Cl}_{2}$ to give corresponding new $\mathrm{Pd}(\mathrm{PN}) \mathrm{Cl}_{2}$ metal complexes, (2a, $\mathbf{2 b}$ and $\mathbf{2 c}$ ). The Heck and Suzuki C-C coupling reactions were examined with catalysts $\mathbf{2 a - 2 c}$ and showed high conversions under the determined conditions with para substituted aryl halides.
\end{abstract}

Keywords: iminophosphine, palladium complexes, Heck coupling, Suzuki coupling

Submitted: October 03, 2017. Accepted: November 23, 2017 .

Cite this: Yılmaz M, Keleş M. The catalytic activity of Palladium(II) complexes containing PN ligands in the Heck and Suzuki C-C coupling reactions. JOTCSA. 2018;5(1):133-48.

DOI: http://dx.doi.org/10.18596/jotcsa.341530.

*Corresponding author. E-mail: mkyilmaz@mersin.edu.tr. Tel.: +90 32436100 01; fax: 90 3243610073. 


\section{INTRODUCTION}

The palladium-catalyzed cross-coupling reactions of aryl halides with arylboronic acids (Suzuki reaction) and with olefins (Heck reaction) provides a powerful methodology for constructing $\mathrm{C}\left(\mathrm{sp}^{2}\right)-\mathrm{C}\left(\mathrm{sp}^{2}\right)$ bonds (1). The reason for the intense research is the fact that $\mathrm{C}-\mathrm{C}$ coupling reactions have been relatively used in several fields such as pharmacological agents, herbicides, and the synthesis of natural products, etc. Consequently, researchers have been working to find better catalysts and achieve better yields in these areas which are important for both industrial and scientific purposes $(2,3)$.

Cyclopalladated catalysts display superior catalytic activities in cross-coupling reactions. Phospha-palladacycles were found to be highly efficient catalysts for Heck and Suzuki coupling reactions (4). Although phosphine ligands and their palladium complexes are widely used to catalyze the cross-coupling reactions for a variety of substrates, there have not been enough publications about the application of the iminophosphines and their palladium complexes in $\mathrm{C}-\mathrm{C}$ coupling reactions. Besides that, the use of iminophosphine ligands, containing both soft phosphorus and hard nitrogen atoms, are generally increases the catalytic activity compared to the homo donor PP and NN ligands. The reason for this is that phosphorus atom can stabilize Pd center in a low oxidation state due to the $\pi$-acceptor character, while $\sigma$-donor ability of the nitrogen atom makes the Pd center more sensitive to the oxidative addition during the catalytic cycle. So PN ligands and their palladium(II) complexes have been identified as efficient catalysts for Heck $(5,6)$ and Suzuki $(7,8)$ reactions.

In this study, we have prepared new palladium(II) complexes (2a-c) to be used in the Heck and Suzuki cross-coupling reactions. The results demonstrate that PN type phosphine palladium(II) complexes are easily synthesized, and are also highly efficient complexes for the C-C crosscoupling reactions.

\section{MATERIALS AND METHODS}

All reactions were carried out under nitrogen or argon atmosphere using conventional Schlenk glassware. All solvents were dried using established procedures and then immediately distilled under nitrogen atmosphere prior to use. 4-amino-3-methylphenol, 4-(2-aminoethyl)phenol, and 2-amino-3-methylpyridine obtained from Sigma-Aldrich Chemie GmbH (Steinheim, Germany) were used without further purification. The $\left[\mathrm{Pd}(\operatorname{cod}) \mathrm{Cl}_{2}\right]$ (9) and 2(diphenylphosphino)benzaldehyde (10) were prepared as described in the literature. 
Yılmaz and Keleş, JOTCSA. 2018; 5(1): 133-148.

Microanalysis was performed using a LECO CHNS 932 instrument. The ${ }^{1} \mathrm{H}$ NMR $(400.1 \mathrm{MHz})$ and ${ }^{31} \mathrm{P}\left\{{ }^{1} \mathrm{H}\right\}$ NMR $(162.0 \mathrm{MHz})$ spectra were recorded at $25{ }^{\circ} \mathrm{C}$ with DMSO- $d_{6}$ and $\mathrm{CDCl}_{3}$ on a Bruker NMR spectrometer; ${ }^{13} \mathrm{C}$ NMR were recorded on a Varian Mercury $100.6 \mathrm{MHz}$ NMR spectrometer. ${ }^{31} \mathrm{P}\left\{{ }^{1} \mathrm{H}\right\}$ NMR spectra were recorded with complete proton decoupling and reported in ppm using $85 \% \mathrm{H}_{3} \mathrm{PO}_{4}$ as external standard. The coupling products were analyzed by a Perkin Elmer Clarus 500 series gas chromatograph equipped with a flame ionization detector and Elite-1 capillary column with $30 \mathrm{~m} \times 0.25 \mathrm{~mm} \times 0.25 \mu \mathrm{m}$ film thickness. Thin-layer chromatography (TLC) was used for monitoring the reactions.

\section{Preparation of $\mathbf{P d ( I I ) ~ c o m p l e x e s ~}$}

The 1a-c were prepared as described in the literature (11).

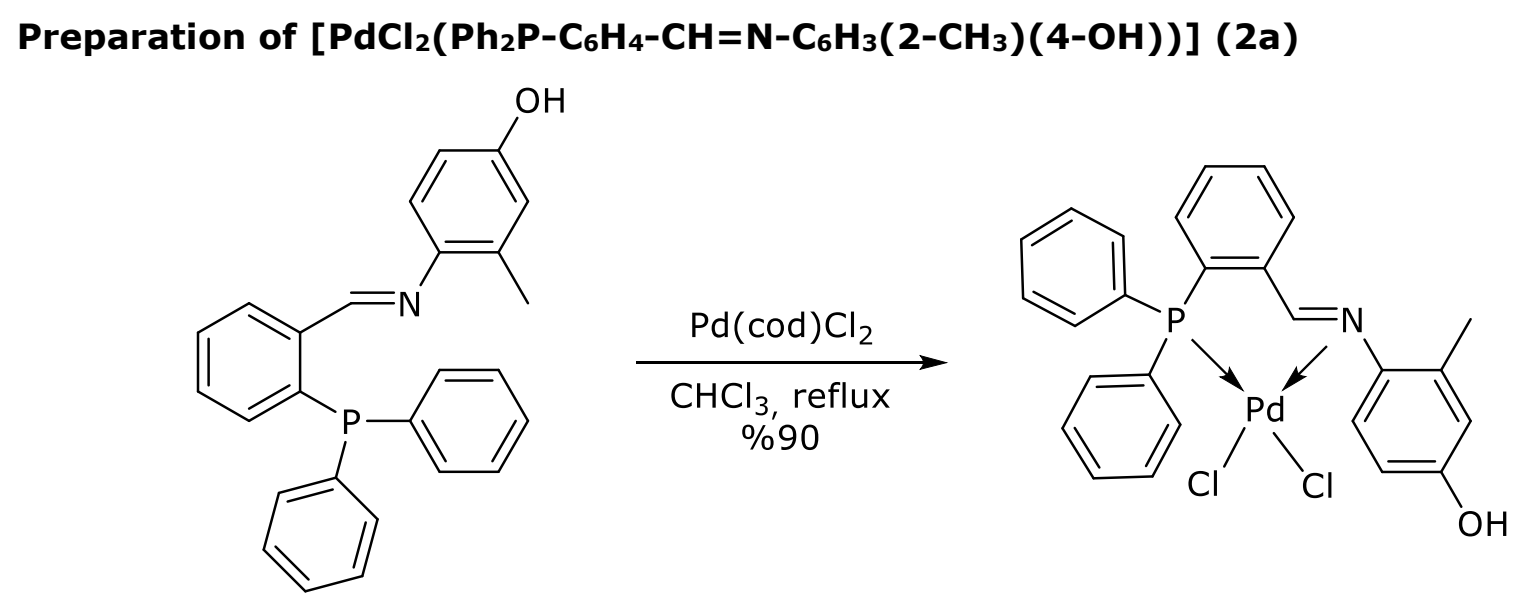

Scheme 1: Synthesis of complex $\mathbf{2 a}$.

To a solution of $\mathrm{Pd}(\mathrm{cod}) \mathrm{Cl}_{2}(145 \mathrm{mg}, 0.51 \mathrm{mmol})$ in $\mathrm{CHCl}_{3}(10 \mathrm{~mL})$ was added 1a $(200 \mathrm{mg}, 0.51$ $\mathrm{mmol}$ ). The mixture was stirred for $6 \mathrm{~h}$. Then the addition of diethyl ether caused to form a yellow solid which was filtered off and dried to give the title compound $\mathbf{2 a}$. Yield $263 \mathrm{mg}$ (90\%), mp.: $255-256{ }^{\circ} \mathrm{C} .{ }^{1} \mathrm{H}$ NMR $\left(400.1 \mathrm{MHz}\right.$, DMSO- $\left.d_{6}\right): \delta(\mathrm{ppm}) 9.47(\mathrm{~s}, 1 \mathrm{H}), 8.59(\mathrm{~s}, 1 \mathrm{H}), 8.20-8.12$ (dd, J=6.9, 4.2 Hz, 1H), $7.95(t, J=8.3 \mathrm{~Hz}, 1 \mathrm{H}), 7.81(\mathrm{t}, J=7.6 \mathrm{~Hz} 1 \mathrm{H}), 7.73-7.69(\mathrm{~m}, 2 \mathrm{H})$, 7.65-7.59 (m, 4H), 7.54-7.48 (m, 4H), $7.02(\mathrm{dd}, J=10.3,7.8 \mathrm{~Hz}, 1 \mathrm{H}), 6.78-6.74(\mathrm{~m}, 1 \mathrm{H}), 6.58-$ $6.52(\mathrm{~m}, 2 \mathrm{H}), 2.09(\mathrm{~s}, 3 \mathrm{H}) .{ }^{13} \mathrm{C} \mathrm{NMR}\left(100.6 \mathrm{MHz}, \mathrm{DMSO}-\mathrm{d}_{6}\right): \delta(\mathrm{ppm}) 168.12\left(\mathrm{~d}, J_{P C}=8.9 \mathrm{~Hz}\right.$, $1 C, \underline{\mathrm{C}} \mathrm{H}=\mathrm{N}), 156.06(\mathrm{~s}, 1 \mathrm{C}), 143.93(\mathrm{~s}, 1 \mathrm{C}), 137.77\left(\mathrm{~d}, \mathrm{~J}_{P C}=8.6 \mathrm{~Hz}, 1 \mathrm{C}\right), 136.55\left(\mathrm{~d}, J_{P C}=15.7 \mathrm{~Hz}\right.$, 2C), $134.87\left(d, J_{P C}=7.4 \mathrm{~Hz}, 1 C\right), 133.95(\mathrm{~s}, 1 \mathrm{C}), 133.53\left(\mathrm{~d}, J_{P C}=11.0 \mathrm{~Hz}, 4 \mathrm{C}\right), 132.28\left(\mathrm{~d}, J_{P C}=2.7\right.$ $\mathrm{Hz}, 1 \mathrm{C}), 131.27(\mathrm{~s}, 1 \mathrm{C}), 129.16\left(\mathrm{~d}, \mathrm{~J}_{P C}=11.8 \mathrm{~Hz}, 4 \mathrm{C}\right), 126.44(\mathrm{~s}, 1 \mathrm{C}), 125.84(\mathrm{~s}, 1 \mathrm{C}), 124.53$ $(\mathrm{s}, 2 \mathrm{C}), 119.88(\mathrm{~s}, 1 \mathrm{C}), 116.62(\mathrm{~s}, 1 \mathrm{C}), 112.19(\mathrm{~s}, 1 \mathrm{C}), 18.66(\mathrm{~s}, 1 \mathrm{C}) .{ }^{31} \mathrm{P} \mathrm{NMR}(162.0 \mathrm{MHz}$, DMSO- $\left.d_{6}\right): \delta(\mathrm{ppm}) 28.78(\mathrm{~s})$. Anal. calcd. for $\mathrm{C}_{26} \mathrm{H}_{22} \mathrm{Cl}_{2} \mathrm{NOPPd}$ : C, 54.52; $\mathrm{H}, 3.87 ; \mathrm{N}, 2.45 \%$. Found: $\mathrm{C}, 53.73 ; \mathrm{H}, 4.37 ; \mathrm{N}, 2.09 \%$. $\mathbf{2 b}$ and $\mathbf{2 c}$ were prepared as described in procedure $\mathbf{2 a}$. 


\subsubsection{Preparation of $\left[\mathrm{PdCl}_{2}\left(\mathrm{Ph}_{2} \mathrm{P}-\mathrm{C}_{6} \mathrm{H}_{4}-\mathrm{CH}=\mathrm{N}-\left(\mathrm{CH}_{2}\right)_{2}-\mathrm{C}_{6} \mathrm{H}_{4}-(4-\mathrm{OH})\right)\right]$ (2b)}
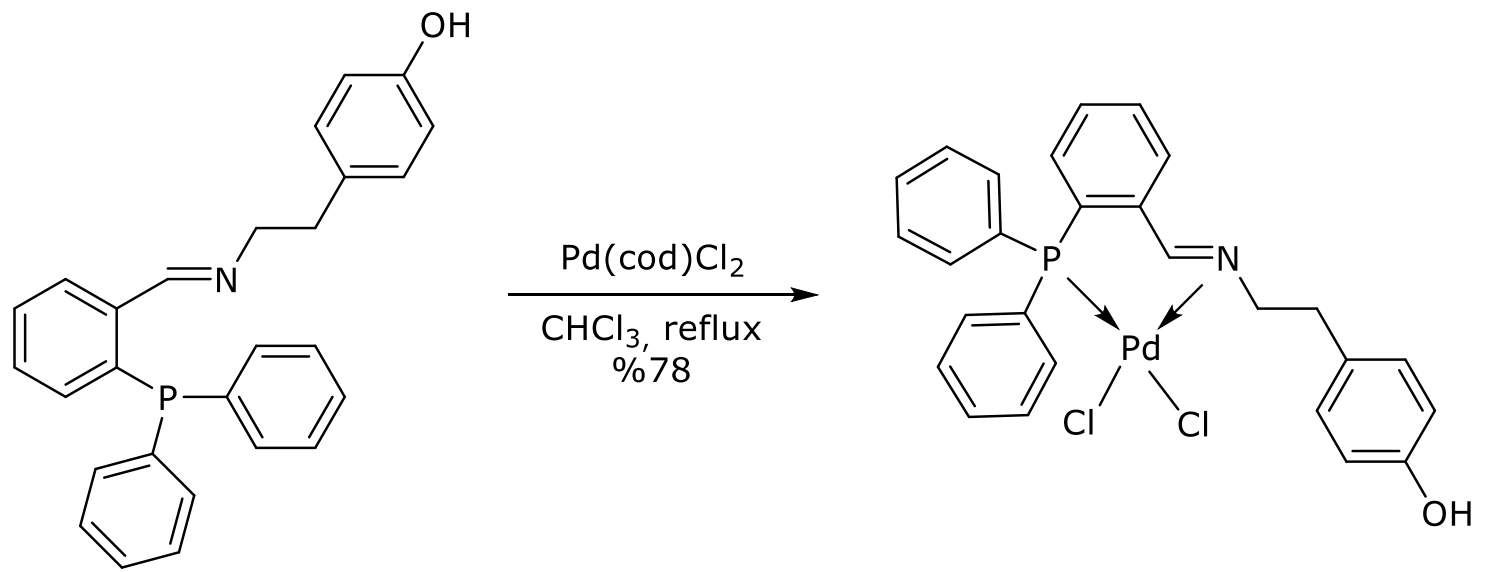

Scheme 2: Synthesis of complex 2b.

Yield $233 \mathrm{mg}(78 \%)$, mp.: 203-204 ${ }^{\circ} \mathrm{C} .{ }^{1} \mathrm{H}$ NMR (400.1 MHz, DMSO-d 6 ): $\delta(\mathrm{ppm}) 9.23(\mathrm{~s}, \mathrm{OH}$, $1 \mathrm{H}), 8.53(\mathrm{~s}, \mathrm{CH}=\mathrm{N}, 1 \mathrm{H}), 7.96-7.90(\mathrm{~m}, 2 \mathrm{H}), 7.78(\mathrm{t}, J=7.5 \mathrm{~Hz} 1 \mathrm{H}), 7.71(\mathrm{td}, J=6.4,1.0 \mathrm{~Hz}$, $2 \mathrm{H}), 7.61(\mathrm{td}, J=7.6,2.7 \mathrm{~Hz}, 4 \mathrm{H}), 7.47(\mathrm{dd}, J=12.9,7.3 \mathrm{~Hz}, 4 \mathrm{H}), 7.01(\mathrm{dd}, J=10.0,8.0 \mathrm{~Hz}, 1 \mathrm{H})$, $6.80(\mathrm{~d}, J=8.4 \mathrm{~Hz}, 2 \mathrm{H}), 6.59(\mathrm{~d}, J=8.4 \mathrm{~Hz}, 2 \mathrm{H}), 4.46\left(\mathrm{t}, J=15.5 \mathrm{~Hz}, \mathrm{NCH}_{2}, 2 \mathrm{H}\right), 2.69(\mathrm{t}, J=15.6$ $\left.\mathrm{Hz}, \mathrm{CH}_{2} \mathrm{Ph}, 2 \mathrm{H}\right) .{ }^{13} \mathrm{C} N M R\left(100.6 \mathrm{MHz}, \mathrm{DMSO}-d_{6}\right): \delta(\mathrm{ppm}) 165.70\left(\mathrm{~d}, J_{P C}=8.9 \mathrm{~Hz}, 1 \mathrm{C}, \underline{\mathrm{C}} \mathrm{H}=\mathrm{N}\right)$, $155.86(\mathrm{~s}, 1 \mathrm{C}), 136.72\left(\mathrm{~d}, J_{P C}=16.1 \mathrm{~Hz}, 1 \mathrm{C}\right), 136.50\left(\mathrm{~d}, J_{P C}=8.6 \mathrm{~Hz}, 4 \mathrm{C}\right), 134.30\left(\mathrm{~d}, J_{P C}=7.9 \mathrm{~Hz}\right.$, 1C), $133.72\left(d, J_{P C}=11.1 \mathrm{~Hz}, 2 \mathrm{C}\right), 133.34\left(\mathrm{~d}, J_{P C}=2.2 \mathrm{~Hz}, 1 \mathrm{C}\right), 132.33\left(\mathrm{~d}, J_{P C}=2.7 \mathrm{~Hz}, 1 \mathrm{C}\right), 129.46$ $(s, 1 C), 129.08$ (d, J $\left.J_{P C}=11.9 \mathrm{~Hz}, 4 \mathrm{C}\right), 127.55$ (s, 1C), $125.99(\mathrm{~s}, 1 \mathrm{C}), 125.39(\mathrm{~s}, 1 \mathrm{C}), 119.72$ (d, $\left.J_{P C}=9.6 \mathrm{~Hz}, 4 \mathrm{C}\right), 115.19(\mathrm{~s}, 1 \mathrm{C}), 66.82(\mathrm{~s}, 1 \mathrm{C}), 35.93(\mathrm{~s}, 1 \mathrm{C}) .{ }^{31} \mathrm{P}$ NMR $\left(162.0 \mathrm{MHz}, \mathrm{DMSO}-d_{6}\right)$ : $\delta(\mathrm{ppm}) 30.93$ (s). Anal. calcd. for $\mathrm{C}_{27} \mathrm{H}_{24} \mathrm{Cl}_{2} \mathrm{NOPPd}$ : C, 55.27; $\mathrm{H}, 4.12 ; \mathrm{N}, 2.39$ \%. Found: C, $54.67 ; \mathrm{H}, 4.67 ; \mathrm{N}, 2.17 \%$.

\subsubsection{Preparation of $\left[\mathrm{PdCl}_{2}\left(\mathrm{Ph}_{2} \mathrm{P}-\mathrm{C}_{6} \mathrm{H}_{4}-\mathrm{CH}=\mathrm{N}-\mathrm{C}_{6} \mathrm{H}_{3} \mathrm{~N}-\left(2-\mathrm{CH}_{3}\right)\right)\right]$ (2C)}<smiles>Cc1cccnc1/N=C/c1ccccc1P(c1ccccc1)c1ccccc1</smiles>

$$
\frac{\mathrm{Pd}(\text { cod }) \mathrm{Cl}_{2}}{\underset{\substack{\mathrm{CHCl}_{3}, \text { reflux } \\ \text { \%88 }}}{\mathrm{C}}}
$$

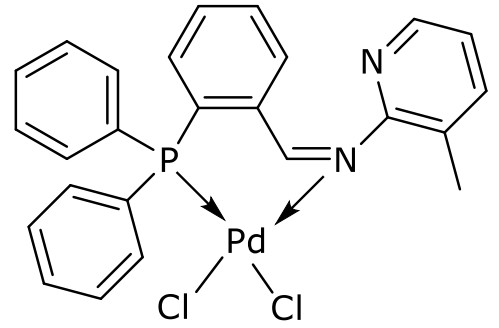

Scheme 3: Synthesis of complex 2c.

Yield $250 \mathrm{mg}(88 \%)$, mp.: $165{ }^{\circ} \mathrm{C} .{ }^{1} \mathrm{H}$ NMR (400.1 MHz, DMSO- $\left.d_{6}\right): \delta(\mathrm{ppm}) 8.82(\mathrm{~s}, 1 \mathrm{H}, \mathrm{HC}=\mathrm{N})$, 8.31-8.24 (m, 2H), $7.98(t, J=7.6 \mathrm{~Hz}, 1 \mathrm{H}), 7.87(\mathrm{t}, J=7.6 \mathrm{~Hz}, 1 \mathrm{H}), 7.72-7.66(\mathrm{~m}, 3 \mathrm{H}), 7.66-$ 
$7.59(\mathrm{~m}, 6 \mathrm{H}), 7.56(\mathrm{~d}, J=7.2 \mathrm{~Hz}, 2 \mathrm{H}), 7.29(\mathrm{dd}, J=7.6,4.8 \mathrm{~Hz}, 1 \mathrm{H}), 7.17(\mathrm{dd}, J=10.1,7.9 \mathrm{~Hz}$, $1 \mathrm{H}), 2.25\left(\mathrm{~s}, 3 \mathrm{H}, \mathrm{CH}_{3}\right) .{ }^{13} \mathrm{C}$ NMR $\left(100.6 \mathrm{MHz}, \mathrm{DMSO}-\mathrm{d}_{6}\right): \delta(\mathrm{ppm}) 168.93\left(\mathrm{~d}, J_{P C}=8.5 \mathrm{~Hz}, \underline{\mathrm{CH}}=\mathrm{N}\right)$, 161.53 (s, 1C), 145.06 (s, 1C), 139.31 (s, 1C), 138.83 (d, JPC $=8.4 \mathrm{~Hz}, 2 \mathrm{C}$ ), 135.81 (d, JPC $=15.7$ $\mathrm{Hz}, 1 \mathrm{C}), 135.52\left(\mathrm{~d}, J_{P C}=7.5 \mathrm{~Hz}, 2 \mathrm{C}\right), 134.43(\mathrm{~s}, 1 \mathrm{C}), 133.67$ (d, $\left.J_{P C}=11.0 \mathrm{~Hz}, 2 \mathrm{C}\right), 132.20(\mathrm{~d}$, $\left.J_{P C}=2.6 \mathrm{~Hz}, 1 \mathrm{C}\right), 129.06\left(\mathrm{~d}, J_{P C}=11.9 \mathrm{~Hz}, 4 \mathrm{C}\right), 128.40(\mathrm{~s}, 1 \mathrm{C}), 126.79(\mathrm{~s}, 1 \mathrm{C}), 126.26(\mathrm{~d}$, $\left.J_{P C}=14.1 \mathrm{~Hz}, 4 \mathrm{C}\right), 123.22(\mathrm{~s}, 1 \mathrm{C}), 18.10\left(\mathrm{~s}, 1 \mathrm{C}, \underline{\mathrm{CH}}_{3}\right) .{ }^{31} \mathrm{P} \mathrm{NMR}\left(162.0 \mathrm{MHz}, \mathrm{DMSO}-d_{6}\right): \delta(\mathrm{ppm})$ 28.03 (s). FT-IR, $\left(\mathrm{KBr}, \mathrm{cm}^{-1}\right)$ u: $3063\left(\mathrm{CH}_{\mathrm{Ar}}\right), 2982\left(\mathrm{CH}_{3}\right), 1614(\mathrm{C}=\mathrm{N}), 1432(\mathrm{P}-\mathrm{Ph})$. Anal. calcd. for $\mathrm{C}_{25} \mathrm{H}_{21} \mathrm{Cl}_{2} \mathrm{~N}_{2} \mathrm{PPd}$ : $\mathrm{C}, 53.84 ; \mathrm{H}, 3.80 ; \mathrm{N}, 5.02 \%$. Found: $\mathrm{C}, 54.69 ; \mathrm{H}, 3.34 ; \mathrm{N}, 4.00 \%$.

\section{General procedure for the Heck coupling reaction}

A Schlenk tube was charged with the base $(1.20 \mathrm{mmol})$ and the organic solvent $(2.0 \mathrm{~mL})$ under nitrogen atmosphere followed by aryl halide $(1.00 \mathrm{mmol})$, olefin $(1.20 \mathrm{mmol})$, and Pd(II) catalyst $(1.00 \% \mathrm{~mol})$. The flask was sealed under $\mathrm{N}_{2}$ atmosphere and placed in an oil bath and then the reaction mixture was stirred at appropriate temperatures for required times. After completion of the reaction, the mixture was cooled and extracted with ethyl acetate $(3 \times 20 \mathrm{~mL})$. The extracts were washed with brine and dried over $\mathrm{MgSO}_{4}$ and then the solvent was evaporated.

\section{General procedure for the Suzuki coupling reaction}

A Schlenk tube was charged with the base $(2.00 \mathrm{mmol})$ and the organic solvent/ $\mathrm{H}_{2} \mathrm{O}(3.0 / 3.0$ $\mathrm{mL}$ ) under nitrogen atmosphere followed by aryl halide $(1.00 \mathrm{mmol})$, phenylboronic acid $(1.50$ $\mathrm{mmol}$ ) and $\mathrm{Pd}(\mathrm{II})$ catalyst $\left(1.00 \% \mathrm{~mol}\right.$ ). The flask was sealed under $\mathrm{N}_{2}$ atmosphere and placed in an oil bath and then the reaction mixture was stirred at appropriate temperatures for required times. The reaction mixture was cooled and poured into water $(5 \mathrm{~mL})$ and extracted with $\mathrm{CHCl}_{3}$ $(3 \times 20 \mathrm{~mL})$. The extracts were washed with brine and dried over $\mathrm{MgSO}_{4}$ and the solvent was then evaporated.

\section{RESULTS AND DISCUSSION}

The ligands, 1a-c, were previously synthesized by treating 2-(diphenylphosphino)benzaldehyde (o- $\left.\mathrm{Ph}_{2} \mathrm{PPhCHO}\right)$ with appropriate primary amines 4-amino-3-methylphenol, 4-(2aminoethyl)phenol and 2-amino-3-methylpyridine, respectively. The Pd(II) complexes (2a-2c) of the iminophosphine ligands were prepared under argon atmosphere using Schlenk techniques as shown in Schemes 1-3.

\section{Characterization of the iminophosphine ligands and their Pd(II) complexes}

The synthesized compounds were characterized using $\mathrm{FT}-\mathrm{IR}$ and ${ }^{1} \mathrm{H},{ }^{13} \mathrm{C}$, and ${ }^{31} \mathrm{P}-\mathrm{NMR}$. Quantizations were carried out with elemental analysis. 
The $\mathrm{VN}_{\mathrm{N}} \mathrm{H}$ and $\mathrm{V} \mathrm{C}=\mathrm{O}$ bands in the free amine and aldehyde compounds have totally disappeared in Schiff base ligands after the condensation. The displacement of $\mathrm{C}=\mathrm{N}$ stretching frequencies from 1610-1636 cm-1 (1a: 1620, 1b: 1636, 1c:1610 (11)) in the free Schiff base ligands to lower values of $1603-1613 \mathrm{~cm}^{-1}$ (2a: 1603, 2b: 1613, 2c: $1604 \mathrm{~cm}^{-1}$ ) in the complexes indicating the coordination of imine nitrogen to the palladium center (12-16).

\section{${ }^{1} H$ NMR evaluation of the compounds}

The ${ }^{1} \mathrm{H}$ NMR spectrum of complexes $2 \mathrm{a}$-c displayed singlets at $\delta 8.59,8.53$, and $8.82 \mathrm{ppm}$, respectively, which confirmed the coordination of the imine $(-\mathrm{CH}=\mathrm{N})$ nitrogen to the palladium center (free ligands; 1a; 8.89 ppm, 1b; 8.88 ppm, and 1c; 9.57 ppm) (11,17-20). On the other hand, ${ }^{1} \mathrm{H}$-NMR spectra of the compounds demonstrate that the $-\mathrm{OH}$ peaks for $\mathbf{2} \mathbf{a}$ and $\mathbf{2} \mathbf{b}$ were observed at 9.47 and 9.43 ppm, respectively. As in the complexes -OH peaks slightly shifted to downfield comparing to the iminophosphine ligands. The aliphatic $-\mathrm{CH}_{3}$ peaks in the structure of 2a (2.09 ppm) and 2c (2.25 ppm) appeared as a singlet, and the $-\mathrm{CH}_{2}-\mathrm{CH}_{2}$ peaks were found as triplet in the structure of $\mathbf{2 b}$ occurring at $2.69\left(\mathrm{~N}-\mathrm{CH}_{2}\right)$ and $4.46 \mathrm{ppm}\left(\mathrm{CH}_{2} \mathrm{Ph}\right)(21,22)$.

\section{${ }^{13} \mathrm{C}$ NMR evaluation of the compounds}

According to the ${ }^{13} \mathrm{C}-\mathrm{NMR}$ spectra of the ligands, the peaks of the imine $(-\underline{\mathrm{C}} \mathrm{H}=\mathrm{N})$ carbon appeared in the region between 161.1 and $155.3 \mathrm{ppm}$ indicating that the iminophosphine ligands were formed from the reaction of 2-(diphenylphosphino)benzaldehyde and amines (23). Furthermore, the $-\mathrm{C}-\mathrm{OH}$ peaks for $\mathbf{1 a}, \mathbf{1 b}, \mathbf{2 a}$ and $\mathbf{2 b}$ appeared at 156.50, 156.06, 156.52 and $155.86 \mathrm{ppm}$, respectively. The $-\mathrm{CH}_{3}$ peaks in the structure of $\mathbf{1} \mathbf{a}$ and $\mathbf{2 a}$ appear at 17.54 and $18.66 \mathrm{ppm}$ as for the $-\mathrm{CH}_{2}-\mathrm{CH}_{2}$ - peaks in the structure of $\mathbf{2} \mathbf{b}$ occur at $66.82\left(\mathrm{~N}-\mathrm{CH}_{2}\right)$ and 35.93 $\left(\mathrm{CH}_{2} \mathrm{Ph}\right) \mathrm{ppm}$. The ${ }^{13} \mathrm{C}$ NMR peaks of the phenyl carbons appeared at 143.93-112.19 (2a), 136.72-115.19 (2b) and 145.06-123,22 ppm (2c) (24).

\section{P NMR Evaluation of the Compounds}

${ }^{31}$ P-NMR peaks appeared at -13.54 (1a), -13.97 (1b), -13.76 (1c), $28.78(\mathbf{2 a}), 30.93$ (2b) and 28.03 (2c), respectively. The ${ }^{31} \mathrm{P}$ NMR signals of the complexes which appeared downfield shift shows that the ligands are coordinated to the palladium center via phosphorus atom (25). Based on NMR and FT-IR analysis of the ligands and palladium complexes, the ligands are coordinated to the palladium atom through the imine nitrogen and the phosphorus atom $(26,27)$.

Elemental analysis for $\mathrm{C}, \mathrm{H}$ and $\mathrm{N}$ of ligands $\mathbf{1 a - 1} \mathbf{c}$ and $\mathrm{Pd}(\mathrm{II})$ complexes $\mathbf{2 a - 2 c}$ have indicated that the metal-ligand ratio of complexes was $1: 1$. 


\section{Heck Reaction}

First of all, the optimal conditions for the catalytic application of $\mathrm{Pd}(\mathrm{II})$ complexes in Heck reaction were identified. Different bases $\left(\mathrm{NEt}_{3}, \mathrm{Na}_{2} \mathrm{CO}_{3}, \mathrm{NaOAC}\right.$ and $\left.\mathrm{K}_{2} \mathrm{CO}_{3}\right)$, different temperatures $\left(80,100,120\right.$ and $140^{\circ} \mathrm{C}$ ) and different solvents (toluene, 1,4-dioxane, DMF, and NMP) were tested to determine the optimum conditions. The progress of the reaction was monitored by $\mathrm{GC}$ analysis. Among the preliminary studies, $\mathrm{K}_{2} \mathrm{CO}_{3}$ was found to be best base and the $\mathrm{N}$-methylpyrolidone (NMP) was found to be most suitable solvent at $140{ }^{\circ} \mathrm{C}$. After optimization of the reaction conditions, the reactions of electronically activated and deactivated aryl bromides and aryl chlorides with substituted styrenes were also examined and moderate to good yields were obtained using catalysts $\mathbf{2 a - c}$. The results are given in Table 1 . All of the reactions are performed with 1.0 mol\% of catalysts in NMP as solvent at $140{ }^{\circ} \mathrm{C}$ with $\mathrm{K}_{2} \mathrm{CO}_{3}$ acting as base. 
Yılmaz and Keleş, JOTCSA. 2018; 5(1): 133-148.

Table 1: Reaction of aryl bromides with halogenated styrenes.
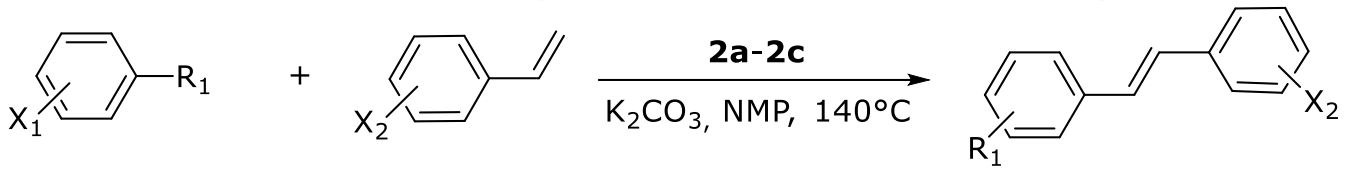

\begin{tabular}{|c|c|c|c|c|c|c|}
\hline \multirow[b]{2}{*}{ Entry } & \multirow[b]{2}{*}{$\mathbf{x}_{1}$} & \multirow[b]{2}{*}{$\mathbf{R}_{\mathbf{1}}$} & \multirow[b]{2}{*}{$\mathbf{X}_{2}$} & \multicolumn{3}{|c|}{ Conv. $(\%)^{a}$} \\
\hline & & & & $2 a$ & 2b & 2c \\
\hline 1 & $\mathrm{o}-\mathrm{Br}$ & $\mathrm{CO}\left(\mathrm{CH}_{3}\right)$ & $\mathrm{o}-\mathrm{Cl}$ & 93 & 42 & 98 \\
\hline 2 & $m-\mathrm{Br}$ & $\mathrm{CO}\left(\mathrm{CH}_{3}\right)$ & $"$ & 96 & 97 & 89 \\
\hline 3 & $p-\mathrm{Br}$ & $\mathrm{CO}\left(\mathrm{CH}_{3}\right)$ & $"$ & 98 & 92 & 94 \\
\hline 4 & $p-\mathrm{Br}$ & $\mathrm{COH}$ & $"$ & 88 & 45 & 71 \\
\hline 5 & $\mathrm{Br}$ & $\mathrm{H}$ & $"$ & 50 & 85 & 17 \\
\hline 6 & $o-\mathrm{Br}$ & $\mathrm{CO}\left(\mathrm{CH}_{3}\right)$ & $m-\mathrm{Cl}$ & 62 & 72 & 14 \\
\hline 7 & $m-\mathrm{Br}$ & $\mathrm{CO}\left(\mathrm{CH}_{3}\right)$ & $"$ & 96 & 99 & 76 \\
\hline 8 & $p-\mathrm{Br}$ & $\mathrm{CO}\left(\mathrm{CH}_{3}\right)$ & $"$ & 98 & 91 & 88 \\
\hline 9 & $p-\mathrm{Br}$ & $\mathrm{COH}$ & $"$ & 93 & 98 & 98 \\
\hline 10 & $\mathrm{Br}$ & $\mathrm{H}$ & $"$ & 58 & 63 & 48 \\
\hline 11 & $\mathrm{o}-\mathrm{Br}$ & $\mathrm{CO}\left(\mathrm{CH}_{3}\right)$ & $p-\mathrm{Cl}$ & 76 & 79 & 87 \\
\hline 12 & $m-\mathrm{Br}$ & $\mathrm{CO}\left(\mathrm{CH}_{3}\right)$ & $"$ & 96 & 98 & 99 \\
\hline 13 & $p-\mathrm{Br}$ & $\mathrm{CO}\left(\mathrm{CH}_{3}\right)$ & $"$ & 94 & 98 & 99 \\
\hline 14 & $p-\mathrm{Br}$ & $\mathrm{COH}$ & $"$ & 85 & 85 & 94 \\
\hline 15 & $\mathrm{Br}$ & $\mathrm{H}$ & $"$ & 87 & 49 & 75 \\
\hline 16 & $o-\mathrm{Br}$ & $\mathrm{CO}\left(\mathrm{CH}_{3}\right)$ & $\mathrm{o}-\mathrm{Br}$ & 72 & 17 & 91 \\
\hline 17 & $m-\mathrm{Br}$ & $\mathrm{CO}\left(\mathrm{CH}_{3}\right)$ & $"$ & 64 & 46 & 88 \\
\hline 18 & $p-\mathrm{Br}$ & $\mathrm{CO}\left(\mathrm{CH}_{3}\right)$ & $"$ & 93 & 36 & 95 \\
\hline 19 & $p-\mathrm{Br}$ & $\mathrm{COH}$ & $"$ & 85 & 10 & 91 \\
\hline 20 & $\mathrm{Br}$ & $\mathrm{H}$ & $"$ & 10 & 6 & 7 \\
\hline 21 & $\mathrm{o}-\mathrm{Br}$ & $\mathrm{CO}\left(\mathrm{CH}_{3}\right)$ & $m-\mathrm{Br}$ & 76 & 50 & 59 \\
\hline 22 & $m-\mathrm{Br}$ & $\mathrm{CO}\left(\mathrm{CH}_{3}\right)$ & $"$ & 90 & 97 & 99 \\
\hline 23 & $p-\mathrm{Br}$ & $\mathrm{CO}\left(\mathrm{CH}_{3}\right)$ & $"$ & 97 & 98 & 47 \\
\hline 24 & $p-\mathrm{Br}$ & $\mathrm{COH}$ & $"$ & 60 & 97 & 96 \\
\hline 25 & $\mathrm{Br}$ & $\mathrm{H}$ & $"$ & 12 & 5 & 4 \\
\hline 26 & $\mathrm{o}-\mathrm{Br}$ & $\mathrm{CO}\left(\mathrm{CH}_{3}\right)$ & $p-\mathrm{Br}$ & 72 & 64 & 18 \\
\hline 27 & $m-\mathrm{Br}$ & $\mathrm{CO}\left(\mathrm{CH}_{3}\right)$ & $"$ & 83 & 97 & 98 \\
\hline 28 & $p-\mathrm{Br}$ & $\mathrm{CO}\left(\mathrm{CH}_{3}\right)$ & $"$ & 88 & 78 & 99 \\
\hline 29 & $p-\mathrm{Br}$ & $\mathrm{COH}$ & $"$ & 86 & 90 & 93 \\
\hline 30 & $\mathrm{Br}$ & $\mathrm{H}$ & " & 5 & 1 & 21 \\
\hline
\end{tabular}

aReaction conditions: aryl bromide $(1.00 \mathrm{mmol})$, styrene $(1.20 \mathrm{mmol}), \mathrm{K}_{2} \mathrm{CO}_{3}(1.20 \mathrm{mmol})$ and $0.01 \mathrm{mmol}$ catalyst in NMP $(2.0 \mathrm{~mL}), 140{ }^{\circ} \mathrm{C}, 6 \mathrm{~h}$.

${ }^{b}$ Conversions were determined by GC based on aryl halide. 
The results from the Table 1 indicate that the highest conversion (99\%) (Table 1, entries 12, 13,22 , and 28 ) was achieved with the catalyst $2 c$ for the reaction between $m$ - and $p$-bromo acetophenone, and $m$ - and $p$-bromo styrene and $m$-chloro styrene. The reason why the yield in ortho position is lower than that in $m$ - or $p$ - position is that the substrate is unable to approach to the active center of $\mathrm{Pd}(0)$. The lowest conversion (5\%) (Table 1, entry 30) was observed in the reaction of bromobenzene with $p$-bromostyrene. When $\mathrm{C}(\mathrm{O}) \mathrm{CH}_{3}$ or $\mathrm{C}(\mathrm{O}) \mathrm{H}$ substituted aryl bromides were used, the yields were generally high. $\mathrm{C}(\mathrm{O}) \mathrm{CH}_{3}$ or $\mathrm{C}(\mathrm{O}) \mathrm{H}$ groups activate the phenyl ring and it results in a higher yield. In general, the conversions were high in the test reactions conducted with aryl halides including electron-withdrawing groups as the substitutes. The conversion rates came out lower in the coupling reactions of bromobenzene. In addition, some low conversions are determined due to the occurrence of palladium black and its influence on the reaction rate (Table 1 , entry $25,30,50$, and 60$)(28,29)$.

Table 2: Palladium-catalyzed coupling reactions of 2-bromo-6-methoxy naphthalene with styrenes ${ }^{\mathrm{a}}$.

\begin{tabular}{ccccc} 
Entry & $\mathbf{R}$ & $\mathbf{2 a}$ & $\mathbf{2 0}$ & $\mathbf{2 0}$ \\
\hline $\mathbf{1}$ & $0-\mathrm{Cl}$ & 38 & 60 & 55 \\
$\mathbf{2}$ & $m-\mathrm{Cl}$ & 70 & 56 & 63 \\
$\mathbf{3}$ & $p-\mathrm{Cl}$ & 92 & 79 & 79 \\
$\mathbf{4}$ & $0-\mathrm{Br}$ & 27 & 16 & 19 \\
$\mathbf{5}$ & $m-\mathrm{Br}$ & 32 & 23 & 15 \\
$\mathbf{6}$ & $p-\mathrm{Br}$ & 17 & 28 & 16 \\
$\mathbf{7}$ & $0-\mathrm{CH}_{3}$ & 57 & 61 & 45 \\
$\mathbf{8}$ & $m-\mathrm{CH}_{3}$ & 72 & 84 & 84 \\
$\mathbf{9}$ & $p-\mathrm{CH}_{3}$ & 95 & 77 & C.r. \\
$\mathbf{1 0}$ & $0-\mathrm{OCH}_{3}$ & 99 & 37 & 93
\end{tabular}

aReaction conditions: 2-bromo-6-methoxy naphthalene (1.00 mmol),
olefin $(1.20 \mathrm{mmol}), \mathrm{K}_{2} \mathrm{CO}_{3}(1.2 \mathrm{mmol})$ and $0.01 \mathrm{mmol}$ catalyst in NMP (2
$\mathrm{mL}), 140{ }^{\circ} \mathrm{C}, 6 \mathrm{~h}$.
${ }^{\text {b } C o n v e r s i o n s ~ w e r e ~ d e t e r m i n e d ~ b y ~ G C ~ b a s e d ~ o n ~ a r y l ~ h a l i d e . ~}$

Finally, Heck reaction was carried out with 2-bromo-6-methoxynaphthalene which is an important chemical in medicinal chemistry and used in the synthesis of naproxen (30). In the reaction between the substituted styrenes and 2-bromo-6-methoxynaphthalene using the 
catalyst 2a o-methoxy styrene gave the highest conversion (99\%) (Table 2, entry 10) while $p$ bromo styrene gave the lowest conversion (17\%) (Table 2, entry 6). The reaction yield was found high when active groups such as -methyl and -methoxy bound to the phenyl ring. It was determined to be low when halogens were used. This is because -methoxy or -methyl groups increase the interest of the substrates to $\mathrm{Pd}(0)$, and it causes an easier binding. When halogens on the phenyl ring are compared, the conversion found from the -chloro attached to phenyl ring was partially higher than that of the -bromo attached to phenyl ring (Table 2). The electronwithdrawing effect of -chloro group is higher than that of -bromo group, and it reduces the electron density of 2-bromo-6-methoxy naphthalene. This increases the interest of 2-bromo-6methoxy naphthalene to $\operatorname{Pd}(0)$.

\section{Suzuki Reaction}

The same way as in the Heck C-C coupling reaction, firstly, the optimal conditions for defining the catalytic efficiency of Pd(II) complexes were determined for the Suzuki reaction. In order to determine the optimal conditions, organic and inorganic bases ( $\mathrm{NEt}_{3}, \mathrm{Na}_{2} \mathrm{CO}_{3}, \mathrm{NaOAc}$, and $\left.\mathrm{K}_{2} \mathrm{CO}_{3}\right)$, different temperatures $\left(80,100,120\right.$, and $140{ }^{\circ} \mathrm{C}$ ) and solvents (toluene, 1,4-dioxane, DMF and NMP) were tested in the reaction of bromo benzene and phenyl boronic acid. At the end of the reaction, samples were analyzed with GC. The results confirm that the conversion was low at $80^{\circ} \mathrm{C}$ in NMP when compared to other solvents such as toluene, 1,4-dioxane, and DMF.

After determining optimal conditions, the results showed that the conversion rose up to as high as 99 percent at the temperature of $80{ }^{\circ} \mathrm{C}$, in the presence of $\mathrm{Na}_{2} \mathrm{CO}_{3}$ in the DMF solvent. The catalytic experiments were conducted with different aryl halide and boronic acid derivatives at 80 and $25^{\circ} \mathrm{C}$ (31). Comparing among -bromo acetophenones, p-bromo acetophenone is slightly higher than ortho- and $m$-bromo acetophenone (Table 3, entries 3, 8 and 13). The bromopositioned at meta- and para- causes a steric hindrance, and it results in partially low conversion. Therefore, the substrate cannot be coordinated to the Pd center well. 
Yılmaz and Keleş, JOTCSA. 2018; 5(1): 133-148.

Table 3: The results of the reactions between aryl bromide and 2-naphthalene boronic acid.<smiles>[X]c1cccc([R7])c1</smiles>

\begin{tabular}{|c|c|c|c|c|c|}
\hline \multirow{2}{*}{ Entry } & \multirow{2}{*}{ Catalyst } & \multirow{2}{*}{$x$} & \multirow{2}{*}{$\mathbf{R}$} & \multicolumn{2}{|c|}{ Conv. $(\%)^{a}$} \\
\hline & & & & $25^{\circ} \mathrm{C}$ & $80^{\circ} \mathrm{C}$ \\
\hline 1 & $2 a$ & $\mathrm{o}-\mathrm{Br}$ & $\mathrm{CO}\left(\mathrm{CH}_{3}\right)$ & 60 & 65 \\
\hline 2 & $"$ & $m-\mathrm{Br}$ & $\mathrm{CO}\left(\mathrm{CH}_{3}\right)$ & 53 & 55 \\
\hline 3 & $"$ & $p-\mathrm{Br}$ & $\mathrm{CO}\left(\mathrm{CH}_{3}\right)$ & 69 & 68 \\
\hline 4 & $"$ & $p-\mathrm{Br}$ & $\mathrm{C}(\mathrm{O}) \mathrm{H}$ & 77 & 79 \\
\hline 5 & $"$ & $\mathrm{Br}$ & $\mathrm{H}$ & 65 & 68 \\
\hline 6 & 2b & $o-\mathrm{Br}$ & $\mathrm{CO}\left(\mathrm{CH}_{3}\right)$ & 2 & 9 \\
\hline 7 & $"$ & $m-\mathrm{Br}$ & $\mathrm{CO}\left(\mathrm{CH}_{3}\right)$ & 10 & 63 \\
\hline 8 & $"$ & $p-\mathrm{Br}$ & $\mathrm{CO}\left(\mathrm{CH}_{3}\right)$ & 98 & 98 \\
\hline 9 & $"$ & $p-\mathrm{Br}$ & $\mathrm{C}(\mathrm{O}) \mathrm{H}$ & 85 & 91 \\
\hline 10 & $"$ & $\mathrm{Br}$ & $\mathrm{H}$ & 46 & 49 \\
\hline 11 & $2 c$ & $\mathrm{o}-\mathrm{Br}$ & $\mathrm{CO}\left(\mathrm{CH}_{3}\right)$ & 67 & 82 \\
\hline 12 & $"$ & $m-\mathrm{Br}$ & $\mathrm{CO}\left(\mathrm{CH}_{3}\right)$ & 39 & 54 \\
\hline 13 & $"$ & $p-\mathrm{Br}$ & $\mathrm{CO}\left(\mathrm{CH}_{3}\right)$ & 77 & 89 \\
\hline 14 & $"$ & $p-\mathrm{Br}$ & $\mathrm{C}(\mathrm{O}) \mathrm{H}$ & 80 & 93 \\
\hline 15 & $"$ & $\mathrm{Br}$ & $\mathrm{H}$ & 61 & 66 \\
\hline
\end{tabular}

aReaction conditions: aryl bromide $(1.00 \mathrm{mmol})$, 2-naphthaleneboronic acid (1.20 $\mathrm{mmol}), \mathrm{K}_{2} \mathrm{CO}_{3}(1.20 \mathrm{mmol})$ and $0.01 \mathrm{mmol}$ catalyst in $\left.\mathrm{DMF} / \mathrm{H}_{2} \mathrm{O} 2 / 2 \mathrm{~mL}\right), 6 \mathrm{~h}$.

bConversions were determined by GC based on aryl halide.

According to the GC analyses, the Suzuki reaction of 4-biphenylboronic acid and aryl bromide using the catalyst $\mathbf{2 b}$, the highest conversions of 99 percent (Table 4, entries 8 and 9), were achieved in the reactions with $p$-bromoacetophenone and $p$-bromobenzaldehyde. The reason why the conversions from the aldehyde and ketone group in para position are higher than those for ortho and meta aldehyde and ketone group is that the steric hindrance is low in para position, and it easily coordinates to Pd(II) center (Table 3, entry 6).

For the reaction between biphenyl and aryl bromide, the highest conversion was obtained 74\% at $25{ }^{\circ} \mathrm{C}$ and $92 \%$ at $80{ }^{\circ} \mathrm{C}$. The lowest conversion at 25 and $80{ }^{\circ} \mathrm{C}$ was calculated to be $12 \%$ and $15 \%$, respectively (Table 4, entry 1 ). As shown in Table 4 entry 9, catalyst $\mathbf{2 b}$ gave excellent results for the synthesis of carbaldehyde derivative compounds in the room temperature. 
Table 4. The Suzuki reaction between aryl bromides and 4-biphenylboronic acid.

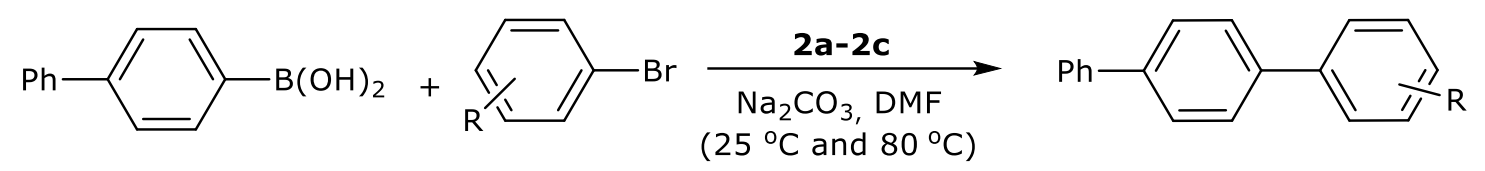

\begin{tabular}{|c|c|c|c|c|}
\hline \multirow{2}{*}{ Entry } & \multirow{2}{*}{ Catalyst } & \multirow{2}{*}{$\mathbf{R}$} & \multicolumn{2}{|c|}{ Conv. $(\%)^{a}$} \\
\hline & & & $25^{\circ} \mathrm{C}$ & $80^{\circ} \mathrm{C}$ \\
\hline 1 & $2 a$ & $o-\mathrm{CO}\left(\mathrm{CH}_{3}\right)$ & 12 & 15 \\
\hline 2 & " & $m-\mathrm{CO}\left(\mathrm{CH}_{3}\right)$ & 25 & 74 \\
\hline 3 & $"$ & $p-\mathrm{CO}\left(\mathrm{CH}_{3}\right)$ & 47 & 67 \\
\hline 4 & $"$ & $p-\mathrm{C}(\mathrm{O}) \mathrm{H}$ & 74 & 92 \\
\hline 5 & $"$ & $\mathrm{H}$ & 60 & 87 \\
\hline 6 & $2 \mathbf{b}$ & $o-\mathrm{CO}\left(\mathrm{CH}_{3}\right)$ & 4 & 20 \\
\hline 7 & $"$ & $m-\mathrm{CO}\left(\mathrm{CH}_{3}\right)$ & 15 & 76 \\
\hline 8 & $"$ & $p-\mathrm{CO}\left(\mathrm{CH}_{3}\right)$ & 91 & 99 \\
\hline 9 & $"$ & $p-\mathrm{C}(\mathrm{O}) \mathrm{H}$ & 99 & 99 \\
\hline 10 & $"$ & $\mathrm{H}$ & 67 & 87 \\
\hline 11 & $2 c$ & $o-\mathrm{CO}\left(\mathrm{CH}_{3}\right)$ & - & 12 \\
\hline 12 & " & $m-\mathrm{CO}\left(\mathrm{CH}_{3}\right)$ & 57 & 66 \\
\hline 13 & $"$ & $p-\mathrm{CO}\left(\mathrm{CH}_{3}\right)$ & 65 & 79 \\
\hline 14 & $"$ & $p-\mathrm{C}(\mathrm{O}) \mathrm{H}$ & 98 & 98 \\
\hline 15 & $"$ & $\mathrm{H}$ & 51 & 65 \\
\hline
\end{tabular}

aReaction conditions: aryl halide $(1.00 \mathrm{mmol}), 4$-biphenylboronic acid $(1.20 \mathrm{mmol})$ $\mathrm{K}_{2} \mathrm{CO}_{3}(1.20 \mathrm{mmol})$ and $0.01 \mathrm{mmol}$ cat., $\left.\mathrm{DMF} / \mathrm{H}_{2} \mathrm{O} 2 / 2 \mathrm{~mL}\right), 6 \mathrm{~h}$.

${ }^{\mathrm{b} C o n v e r s i o n s ~ w e r e ~ d e t e r m i n e d ~ b y ~ G C ~ b a s e d ~ o n ~ a r y l ~ h a l i d e . ~}$

When the catalytic efficiencies were analyzed with GC, the best conversion percentage in the reactions between 2-bromo-6-methoxy naphthalene, 2-naphthalene boronic acid and 4-biphenyl boronic acid was determined to be 91 percent when the catalyst $\mathbf{2} \mathbf{b}$ was used and 69 percent with the catalyst $\mathbf{2 a}$ (Table 5, entries 2-3). As seen in Table 5, the conversions were found to be low or average. Due to the steric effect of the substrates, the substrates are inability to approach to palladium active center, and it results in low conversions. 
Table 5: The results of the reaction between 2-bromo-6-methoxy naphthalene and arylboronic acids.

Entry Catalyst

Reaction conditions: 2-bromo-6-methoxy naphthalene (1 mmol), arylboronic acid (1.20 $\mathrm{mmol}), \mathrm{K}_{2} \mathrm{CO}_{3}(1.20 \mathrm{mmol})$ and $0.01 \mathrm{mmol}$ of catalyst, DMF/water, $2 / 2 \mathrm{~mL}, 6 \mathrm{~h}$. aConversions were determined by GC based on 2-bromo-6-methoxynaphthalene. ${ }^{\mathrm{b}} 25^{\circ} \mathrm{C}$. ${ }^{\mathrm{c}} 80^{\circ} \mathrm{C}$.

\section{CONCLUSIONS}

A new series of iminophosphine-Pd(II) complexes with PN ligands have been synthesized and characterized using spectroscopic techniques. The ${ }^{31} \mathrm{P}\left\{{ }^{1} \mathrm{H}\right\}$ NMR and FTIR results of the complexes indicate that the coordination of the iminophoshine ligand with Pd(II) occurs via phosphorus and nitrogen atoms. The complexes have been tested as catalysts for Heck and Suzuki reactions. The $\mathrm{C}-\mathrm{C}$ coupling reactions put into practice with catalysts $\mathbf{2 a - 2 c}$ show high conversions under the determined conditions with para- substituted aryl halides. Besides, the high conversion of some substrates at $25^{\circ} \mathrm{C}$ shows that the catalysts are active. 


\section{ACKNOWLEDGEMENT}

We thank to the Scientific and Technological Research Council of Turkey (TUBITAK) (Project Number: 112T747) for a grant.

\section{REFERENCES}

1. Aydemir M, Baysal A, Gümgüm B. Synthesis and characterization of tris $\{2-(N, N-$ bis(diphenylphosphino) aminoethyl\} amine derivatives: Application of a palladium(II) complex as a pre-catalyst in the Heck and Suzuki cross-coupling reactions. J Organomet Chem. 2008 Dec;693(26):3810-4.

2. Scrivanti A, Beghetto V, Matteoli U, Antonaroli S, Marini A, Crociani B. Catalytic activity of $\eta 2$ (olefin)palladium( 0 ) complexes with iminophosphine ligands in the Suzuki-Miyaura reaction. Role of the olefin in the catalyst stabilization. Tetrahedron. 2005 Oct;61(41):9752-8.

3. Nadri S, Joshaghani M, Rafiee E. Biphenyl-based phosphine: A well-defined, air-stable, and efficient ligand for the Mizoroki-Heck reaction. Appl Catal Gen. 2009 Jun;362(1-2):163-8.

4. Herrmann WA, Böhm VP., Reisinger C-P. Application of palladacycles in Heck type reactions. J Organomet Chem. 1999 Mar;576(1-2):23-41.

5. Iyer S, Kulkarni GM, Ramesh C. Mizoroki-Heck reaction, catalysis by nitrogen ligand Pd complexes and activation of aryl bromides. Tetrahedron. 2004 Feb;60(9):2163-72.

6. Reddy KR, Surekha K, Lee G-H, Peng S-M, Liu S-T. Palladium(II) Complexes with Phosphorus-Nitrogen Mixed Donors. Efficient Catalysts for the Heck Reaction. Organometallics. 2000 Jun; 19(13):2637-9.

7. Doherty S, Knight JG, Scanlan TH, Elsegood MR, Clegg W. Iminophosphines: synthesis, formation of 2, 3-dihydro-1H-benzo [1, 3] azaphosphol-3-ium salts and N-(pyridin-2-yl)-2diphenylphosphinoylaniline, coordination chemistry and applications in platinum group catalyzed Suzuki coupling reactions and hydrosilylations. J Organomet Chem. 2002;650(1):231-248.

8. Cheng J, Wang F, Xu J-H, Pan Y, Zhang Z. Palladium-catalyzed Suzuki-Miyaura reaction using aminophosphine as ligand. Tetrahedron Lett. 2003;44(37):7095-7098.

9. Drew D, Doyle JR, Shaver AG. Cyclic Diolefin Complexes of Platinum and Palladium. In: Cotton FA, editor. Inorganic Syntheses [Internet]. Hoboken, NJ, USA: John Wiley \& Sons, Inc.; 2007 [cited 2017 Nov 24]. p. 47-55. Available from: http://doi.wiley.com/10.1002/9780470132449.ch11

10. Laue S, Greiner L, Wöltinger J, Liese A. Continuous application of chemzymes in a membrane reactor: Asymmetric transfer hydrogenation of acetophenone. Adv Synth Catal. 2001;343(67):711-720.

11. Keleş M, Şahinoğlu C, Emir DM, Mart M. New iminophosphine-Ru (II) complexes and their application in hydrogenation and transfer hydrogenation. Appl Organomet Chem. 2014;28(10):768772.

12. Nobre SM, Monteiro AL. Pd complexes of iminophosphine ligands: A homogeneous molecular catalyst for Suzuki-Miyaura cross-coupling reactions under mild conditions. J Mol Catal Chem. 2009;313(1):65-73. 
13. Jeffery JC, Rauchfuss TB, Tucker PA. Metal complexes of diiminodiphosphines. Structural and reactivity patterns. Inorg Chem. 1980 Nov;19(11):3306-15.

14. Rülke RE, Kaasjager VE, Wehman P, Elsevier CJ, van Leeuwen PWNM, Vrieze K, et al. Stable Palladium(0), Palladium(II), and Platinum(II) Complexes Containing a New, Multifunctional and Hemilabile Phosphino-Imino-Pyridyl Ligand: Synthesis, Characterization, and Reactivity. Organometallics. 1996 Jan;15(13):3022-31.

15. Crochet P, Gimeno J, Borge J, García-Granda S. Novel ruthenium(ii) complexes containing imino- or aminophosphine ligands for catalytic transfer hydrogenation. New J Chem. 2003 Jan 20;27(2):41420.

16. Kwong H-L, Lee W-S, Lai T-S, Wong W-T. Ruthenium catalyzed asymmetric transfer hydrogenation based on chiral $\mathrm{P}, \mathrm{N}, \mathrm{O}$ Schiff base ligands and crystal structure of a ruthenium(II) complex bearing chiral P,N,O Schiff base ligands. Inorg Chem Commun. 1999 Feb;2(2):66-9.

17. Reddy KR, Surekha K, Lee G-H, Peng S-M, Chen J-T, Liu S-T. Study of Insertion of Olefins and/or Carbon Monoxide into Phosphine- Imine Palladium Methyl Complexes. Organometallics. $2001 ; 20(7): 1292-1299$.

18. Wang C, Friedrich S, Younkin TR, Li RT, Grubbs RH, Bansleben DA, et al. Neutral Nickel(II)-Based Catalysts for Ethylene Polymerization. Organometallics. 1998 Jul;17(15):3149-51.

19. Lavery A, Nelson SM. Dinuclear intermediates in the oxidation of pendant olefinic groups of palladium (II)-co-ordinated Schiff-base ligands. J Chem Soc Dalton Trans. 1984;(4):615-620.

20. Alder MJ, Cross WI, Flower KR, Pritchard RG. Azo-phosphine containing complexes of Group 6 metal carbonyls: crystal and molecular structure of $[\mathrm{Mo}(\mathrm{CO}) 5\{1$-(4-ethylphenylazo)-6-diphenylphosphinonaphthalen-2-ol\}]. J Organomet Chem. 1998 Oct;568(1-2):279-85.

21. Korostylev A, Bondarev O, Lyubimov S, Kovalevsky AY, Petrovskii P, Davankov V, et al. New palladium (II) complexes of (N, N-dimethylamino) alkoxy-1, 3, 2-oxazaphospholidine ligands. Inorganica Chim Acta. 2000;303(1):1-6.

22. Mahamo T, Mogorosi MM, Moss JR, Mapolie SF, Chris Slootweg J, Lammertsma K, et al. Neutral palladium(II) complexes with P,N Schiff-base ligands: Synthesis, characterization and application as Suzuki-Miyaura coupling catalysts. J Organomet Chem. 2012 Apr;703:34-42.

23. Radulović V, Bacchi A, Pelizzi G, Sladić D, Brčeski I, Andjelković K. Synthesis, Structure, and Antimicrobial Activity of Complexes of Pt(II), Pd(II), and $\mathrm{Ni}(\mathrm{II})$ with the Condensation Product of 2(Diphenylphosphino)benzaldehyde and Semioxamazide. Monatshefte Für Chem - Chem Mon. 2006 Jun;137(6):681-91.

24. Mogorosi MM, Mahamo T, Moss JR, Mapolie SF, Slootweg JC, Lammertsma K, et al. Neutral palladium (II) complexes with P, N Schiff-base ligands: Synthesis, characterization and catalytic oligomerisation of ethylene. J Organomet Chem. 2011;696(23):3585-3592.

25. Keleş M, Yılmaz MK. Palladium(II) complexes with aminomethylphosphine ligands as catalysts for the heck reaction. Heteroat Chem. 2012;23(5):466-71.

26. Keles M, Aydin Z, Serindag O. Synthesis of palladium complexes with bis(diphenylphosphinomethyl)amino ligands: A catalyst for the Heck reaction of aryl halide with methyl acrylate. J Organomet Chem. 2007 Apr;692(10):1951-5.

27. Garrou PE. .DELTA.R-ring contributions to phosphorus-31 NMR parameters of transition-metalphosphorus chelate complexes. Chem Rev. 1981 Jun;81(3):229-66. 
Yılmaz and Keleş, JOTCSA. 2018; 5(1): 133-148.

28. Smith RC, Bodner CR, Earl MJ, Sears NC, Hill NE, Bishop LM, et al. Suzuki and Heck coupling reactions mediated by palladium complexes bearing trans-spanning diphosphines. J Organomet Chem. 2005 Jan;690(2):477-81.

29. Pramick MR, Rosemeier SM, Beranek MT, Nickse SB, Stone Jj, Stockland, RA, et al. Coupling of Aryl Halides with Aryl Boronic Acids with $\mathrm{P}\left(\mathrm{C}_{6} \mathrm{H}_{5}\right)\left(2-\mathrm{C}_{6} \mathrm{H}_{4} \mathrm{Cl}\right)_{2}$ as the Supporting Ligand.

Organometallics. 2003 Feb;22(3):523-8.

30. Harrington PJ, Lodewijk E. Twenty Years of Naproxen Technology. Org Process Res Dev. 1997 Jan;1(1):72-6.

31. Sabounchei SJ, Panahimehr M, Ahmadi M, Nasri Z, Khavasi HR. Four-coordinate Pd(II) complexes containing non-symmetric phosphorus ylides: Synthesis, characterization, and catalytic behavior towards Suzuki reaction. J Organomet Chem. 2013 Jan;723:207-13. 